\title{
Commentary: A milestone forgotten
}

\author{
Erle H. Austin, III, MD
}

In the preceding article, Drs Svensson and Mihaljevic ${ }^{1}$ remind us of a forgotten milestone in the history of cardiac surgery. The 1950s were monumental in the origin of techniques for direct vision intracardiac repairs. The first successful application of a heart-lung machine to repair a heart defect was reported by Gibbon in $1953 .{ }^{2}$ Lillehei was the first to successfully close a ventricular septal defect on March 26, 1954, using cross-circulation with a parent for support. ${ }^{3}$ Kirklin was the first to successfully close a ventricular septal defect using a modification of Gibbon's pump on March 25, 1955. Interestingly, in the year 1955 all the open-heart surgery performed anywhere in the world was performed in Minnesota, either by Kirklin or by Lillehei. To the best of our knowledge, neither surgeon "stopped the heart" to perform the repairs.

By the end of 1955, other surgeons, learning from what was happening in Minnesota, began to develop and apply their own adaptations to permit open heart surgery at other centers around the world. Among those centers was the Cleveland Clinic with Donald Effler as surgeon. The Cleveland Clinic had the advantage of Dr Willem Kolff, who was instrumental in developing a membrane oxygenator, a key component of the Cleveland Clinic heart-lung machine. ${ }^{5}$ Kolff also recognized the contribution of Melrose, who determined that the heart could be arrested with aortic occlusion and instillation of a solution of blood and potassium citrate. ${ }^{6}$ The advantage of a "stopped heart" was improved visualization, less blood in the operative field, and prevention of air embolism. Effler and Groves tested this technique

From the Department of Cardiovascular and Thoracic Surgery, University of Louisville, Louisville, Ky.

Disclosures: The author reported no conflicts of interest.

The Journal policy requires editors and reviewers to disclose conflicts of interest and to decline handling or reviewing manuscripts for which they may have a conflict of interest. The editors and reviewers of this article have no conflicts of interest.

Received for publication Aug 31, 2021; revisions received Aug 31, 2021; accepted for publication Sept 2, 2021; available ahead of print Sept 7, 2021.

Address for reprints: Erle H. Austin, III, MD, 201 Abraham Flexner Way, Suite 1200, Louisville, KY 40202 (E-mail: Erle.austin@louisville.edu).

JTCVS Techniques 2021;10:466-7

2666-2507

Copyright (C 2021 The Author(s). Published by Elsevier Inc. on behalf of The American Association for Thoracic Surgery. This is an open access article under the CC BY-NC-ND license (http://creativecommons.org/licenses/by-nc-nd/4.0/).

https://doi.org/10.1016/j.xjtc.2021.09.004

in the laboratory and proceeded to apply it clinically on February 17, 1956 .

The details of the procedure are interesting in that they are similar in many ways to what is done today, 65 years later. It should not be assumed, however, that the use of potassium-induced cardiac arrest as applied by Effler and Groves in 1956 became standard or was universally adopted. In fact, by the early 1960s significant myocardial injury from potassium-induced cardiac arrest was being reported. ${ }^{8,9}$ As such, for at least a decade and a half, the use of potassium-based solutions to arrest the heart was avoided by most cardiac surgeons. Other techniques, including topical hypothermia, intermittent aortic occlusion, and direct coronary artery perfusion, were employed instead. It wasn't until the 1970s and later that a second wave of interest in potassium-based cardioplegia arrived. Gay and Ebert $^{10}$ are often cited for renewing interest when they recognized that the myocardial injury from the Melrose technique was primarily secondary to an excessive concentration of potassium citrate. Since that report, many others $^{11-13}$ have contributed to the development of solutions, most of them potassium-based, that make cardioplegic arrest an accepted and commonly applied technique in open heart surgery today. Despite the stops and starts in the use of cardioplegia, the operation described and depicted herein deserves recognition as an important milestone in cardiac surgery. 


\section{References}

1. Svensson LG, Mihaljevic T. An important cardiac surgery milestone: the first known stopped-heart operation. J Thorac Cardiovasc Surg Tech. 2021;10: 460-3.

2. Gibbon JH Jr. Application of a mechanical heart and lung apparatus to cardiac surgery. Minn Med. 1954;37:171-80.

3. Lillehei CW, Cohen M, Warden HE, Varco RL. The direct-vision correction of congenital anomalies by controlled cross circulation. Surgery. 1955;38: 11-29.

4. Kirklin JW, DuShane JW, Patrick RT, Donald DE, Hetzel PS, Harshbarger HG, et al. Intracardiac surgery with the aid of a mechanical pump-oxygenator (Gibbon type): report of eight cases. Proc Staff Meet Mayo Clin. 1955;30:201-6.

5. Kolff WJ, Effler DB, Groves LK, Peereboom G, Moraca PP. Disposable membrane oxygenator (heart-lung machine) and its use in experimental surgery. Cleve Clin Q. 1956;23:69-97.

6. Melrose DG, Dreyer B, Bentall HH, Baker JBE. Elective cardiac arrest. Lancet. $1955 ; 2: 21$.

7. Effler DB, Groves LK, Sones FM, Kolff WJ. Elective cardiac arrest in open-heart surgery. Cleve Clin Q. 1956;23:105-14.

8. Helmsworth JA, Kaplan S, Clark LC, McAdams AJ, Matthews EC, Edwards FK. Myocardial injury associated with asystole induced with potassium citrate. Ann Surg. 1959;149:200-6.

9. Bjork VO, Fors B. Induced cardiac arrest. J Thorac Cardiovasc Surg. 1961;41: 387-94.

10. Gay WA, Ebert PA. Functional, metabolic, and morphological effects of potassium induced cardioplegia. Surgery. 1973;74:284-90.

11. Bretschneider HJ, Huubner G, Knoll D. Myocardial resistance and tolerance to ischemia: physiological and biochemical basis. J Cardiovasc Surg. 1975;16 241-60.

12. Hearse DJ, Braimbridge MV, Junge P. Principles of cardioplegia. In: Hearse DJ Braimbridge MV, Jynge P, eds. Protection of the Ischaemic Myocardium: Cardioplegia. New York: Raven Press; 1981:151-326.

13. Buckberg GD. Myocardial protection: an overview. Semin Thorac Cardiovasc Surg. 1993;5:98-106. 